\title{
THE EFFECT OF ERYTHROPOIETIN DOSE PHASE OF CORRECTION AS DRUG-RELATED PROBLEMS TO TARGET LEVEL OF HEMOGLOBIN IN REGULAR HEMODIALYSIS PATIENTS
}

\author{
LUTHVIA LUTHVIA ${ }^{1}$, URIP HARAHAP ${ }^{1 *}$, SYAFRIZAL NASUTION ${ }^{2}$ \\ ${ }^{1}$ Department of Pharmacology, Faculty of Pharmacy, Universitas Sumatera Utara, Medan, Indonesia. ${ }^{2}$ Hemodialisis Division, \\ Department of Internal Medicine, Medical Faculty, University of Sumatera Utara/Haji Adam Malik General Hospital, Medan, Indonesia. \\ Email: urip.hrp@gmail.com
}

Received: 16 December 2017, Revised and Accepted: 23 January 2018

ABSTRACT

Objectives: This research aims to know the effect of drug-related problems (DRPs)-related doses against the target hemoglobin levels in hemodialysis (HD) patients in the regular phase of the correction given the therapy of erythropoietin on H. Adam Malik Medan.

Methods: This research was by the cross-sectional, prospective method, using DRP - Registration Form V7.0 (PCNE) against 50 patients. The data were analyzed statistically using Chi-square test, paired t-test sample, and independent t-test, SPSS version 17.

Results: The target hemoglobin not reaching 30 patients (60\%), the level of hemoglobin target exceeded target 1 of the patients (2\%). Based on the results of the test $t$, the value of $\mathrm{p}=0.038<0.05$, then there is a difference in the level of hemoglobin after providing significant erythropoietin therapy between doses and less excess. Test the level of hemoglobin of erythropoietin therapy before and after using a test sample. Paired t-test based on the results, obtained significant value is 0.05 , then $0.015<$ increased hemoglobin level after statistics are given significant therapy of erythropoietin.

Conclusion: The results of this study indicate that there is an effect of DRPs related to excessive dosage; less dose to target hemoglobin level with significant value, so DRPs-associated dose affect the target hemoglobin level.

Keywords: Anemia, Erythropoietin, Drug-related problems, Hemoglobin, Hemodialysis.

(C) 2018 The Authors. Published by Innovare Academic Sciences Pvt Ltd. This is an open access article under the CC BY license (http://creativecommons. org/licenses/by/4. 0/) DOI: http://dx.doi.org/10.22159/ajpcr.2018.v11i5.24313

\section{INTRODUCTION}

Chronic kidney disease (CKD) is a process of pathological changes in renal function and structure, resulting in a progressive decline in renal function and generally ending with renal failure [1]. According to the World Health Organization, globally, over 500 million people have CKD, approximately 1.5 million people have to live by hemodialysis (HD) [2].

HD is a process used in patients with terminal stage renal disease that requires long-term therapy or permanent therapy [3]. Chronic kidney patients undergoing HD will suffer from anemia [4].

Anemia in renal disease if $\mathrm{Hb} \leq 10 \mathrm{~g} / \mathrm{dL}$ and $\mathrm{Ht} \leq 30 \%$, anemia will be more severe if renal function becomes worse, anemia that occurs in CKD is usually normokrom normositer type [5]. Anemia is a big enough problem of maintaining the quality of life of chronic kidney patients, increasing morbidity and mortality [6].

Anemia was defined as $\mathrm{Hb}$ level $<13.0 \mathrm{~g} / \mathrm{dL}$ for men and $<12.0 \mathrm{~g} / \mathrm{dL}$ for women as per the World Health Organization guidelines. CKD was defined as a reduced excretory function with an estimated long fiber granular (glomerular filtration rate) $<60 \mathrm{ml} / \mathrm{min} / 1.73 \mathrm{~m}^{2}$ as a marker of kidney dysfunction [7].

Anemia in CKD is mainly caused by reducing the production of erythropoietin, a hormone that will stimulate the bone marrow to produce red blood cells [8]. Under normal circumstances, $90 \%$ of erythropoietin is produced in the kidneys in the juxtaglomerolus and only $10 \%$ is produced in the liver [9].

Erythropoietin is the preferred treatment of anemia in chronic kidney patients with target $\mathrm{Hb} 11-12 \mathrm{~g} / \mathrm{dL}$, hemoglobin levels more than $13 \mathrm{~g} / \mathrm{dL}$ will increase the risk of thrombosis [10].
Drug-related problems (DRPs) are an event or state of drug therapy that significantly or potentially interferes with the desired outcome of the therapy, recovers from illness, eliminates or reduces symptoms of pain, stops or slows the painful process, and prevents disease or disease symptoms [11]. Identify DRPs criteria including unwanted reaction drugs, drug selection, drug dosage, time, drug interactions, and others [12]. Pharmacists play a key role in identifying and preventing DRPs by conducting interventions with the doctor, patient, and the nurse based on predicted DRPs [13].

Research on DRPs has been largely done on the use of drugs in various cases of illness, including orthopedic open invoice patients [14], in dyspepsia patients [15], in orthopedic post-operative [16]. Based on a search conducted on LITBANG (Research and Development) of RSUP, H. Adam Malik Medan is known that the study of the influence of doses of erythropoietin phase correction as DRPs to target hemoglobin level in the regular HD patient has never been done and the number of cases that occur due to the use of erythropoietin therapy, the importance of the authors to conduct research with the title "The effect of erythropoietin dose phase of correction as DRPs to target level of hemoglobin in regular HD patients."

\section{METHODS}

Research design

This research was by the cross-sectional, prospective method, using DRP - registration Form V7.0 (PCNE) against 50 patients [17]. The data were analyzed statistically using Chi-square test, paired t-test sample, and independent t-test, SPSS version 17.

\section{Data source}

Sources of research data are secondary data in the form of medical records of regular HD patients who receive erythropoietin therapy, laboratory results, and nurse records. 
Place and time of research

The study was conducted at the Hemodialisa Installation of RSUP H. Adam Malik Medan, from August to October 2017.

\section{Population and sample}

Population

The population in this study was the regular HD patient of RSUP $\mathrm{H}$. Adam Malik Medan.

Sample

The selected sample must meet the inclusion criteria and does not meet the exclusion criteria.

Table 1: Frequency distribution based on gender

\begin{tabular}{ll}
\hline Gender & Frequency (\%) \\
\hline Man & $31(62.0)$ \\
Women & $19(38.0)$ \\
Total & $50(100.0)$ \\
\hline
\end{tabular}

Table 2: Frequency distribution by age

\begin{tabular}{ll}
\hline Age (year) & Frequency (\%) \\
\hline $20-30$ & $11(22.0)$ \\
$31-40$ & $7(14.0)$ \\
$41-50$ & $6(12.0)$ \\
$51-60$ & $16(32.0)$ \\
$>60$ & $10(20.0)$ \\
Total & $50(100.0)$ \\
\hline
\end{tabular}

Table 3: Frequency distribution based on attendant diagnosis

\begin{tabular}{ll}
\hline Attendant diagnosis & Frequency (\%) \\
\hline Valid & \\
Diabetes mellitus & $1(2.0)$ \\
Diabetes nephropathy & $3(6.0)$ \\
Chronic glomerulonephritis & $5(10.0)$ \\
Hypertension nephropathy & $33(66.0)$ \\
HN+CHF & $1(2.0)$ \\
Chronic disease obstruksi & $6(12.0)$ \\
Systemic lupus & $1(2.0)$ \\
erythematosus & \\
Total & $50(100.0)$ \\
\hline
\end{tabular}

Table 4: Distribution of frequency based on stage

\begin{tabular}{ll}
\hline Stage & Frequency (\%) \\
5 & $50(100.0)$ \\
\hline
\end{tabular}

The inclusion criteria are as follows:

a. Undergo regular HD

b. Anemic patients

c. Get erythropoietin phase correction therapy.

Exclusion criteria are as follows:

a. Not necessarily get erythropoietin therapy

b. Replace the type of erythropoietin

c. The patient is in an unstable state.

\section{Number of samples}

The sample size was the number of regular HD patients in RSUP. H.

Adam Malik calculated based on the Raosoft program [18], with values:

- $\quad$ The margin of error $=5 \%$

- $\quad$ Confidence level $=95 \%$

- $\quad$ Population size $=100$

- Data installation in HD 2017 RSUP H. Adam Malik Medan

- $\quad$ Response distribution (response distribution) $=50 \%$

- Then obtained a large sample of at least 50 people.

\section{Tools and materials}

Tools used

a. Syringe 3cc

b. Tube EDTA

Materials used

a. Blood.

\section{Research steps}

The steps of this research are carried out as follows:

a. Requesting the recommendation of the Dean of the Faculty of Pharmacy USU to be able to conduct research in RSUP H. Adam Malik Medan

b. Request approval of the Research Ethics Committee in the medical field of Faculty of Medicine, University of North Sumatra, to be approved by the Director of RSUP H. Adam Malik Medan

c. Contact the Director of RSUP H. Adam Malik Medan to obtain permission to conduct research and data retrieval with a letter of recommendation from the Faculty of Pharmacy USU

d. Data collection of erythropoietin therapy given to regular HD patients based on the RSUP Formulary. H. Adam Malik Medan, the list of JAMKESMAS erythropoietin therapy drugs, and List of Askes Price Places Ceiling (DPHO).

e. Choose patients who meet inclusion criteria

f. Data retrieval

g. Data analysis.

\section{Research procedures}

Materials examined were blood taken before and after erythropoietin therapy, examined by clinical pathology laboratory workers at RSUP H. Adam Malik Medan. Measurement of this tool is using Sysmex G 20 engine.

Table 5: Effect of dose-related DRPs less and excess of the target hemoglobin

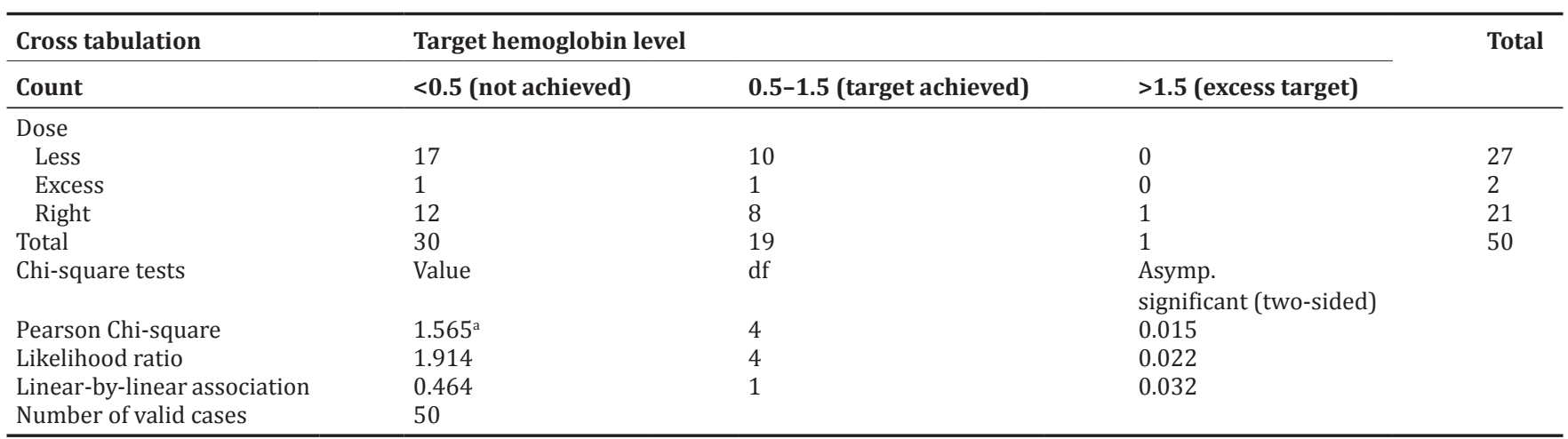


Analysis of samples is using whole blood mode. Working procedure of this tool checks the status of LED indicator on tool and sampler under READY condition. Click the Analysis Button sampler on the control menu. Select discrete test. Click Ok. Put the shelf on the loader sampler [19].

The data collected in this research are:

a. Records of data from medical records in the HD room of RSUP. H. Adam Malik Medan includes data on patient demographic characteristics (sex, age, type of erythropoietin, and stage)

b. Patient data related to the inclusion criteria

c. Patient laboratory data, recorded before and after erythropoietin therapy. Assessment/measurement an increase in hemoglobin levels is done by comparing the results of laboratory data before the patient obtains erythropoietin therapy was compared with laboratory results after patients received erythropoietin therapy

d. The captured data are moved to the data collection sheet. The lack of medical record data is supplemented by looking at nurse records, SIRS data, and pharmaceutical depot drug records.

\section{Data analysis}

Data were analyzed statistically using Chi-square test, paired t-test sample, and independent t-test, SPSS version 17 program.

\section{RESULTS AND DISCUSSION}

\section{RESULTS}

The study was conducted on 50 patients with chronic renal HD at a HD hospital in Haji Adam Malik General Hospital Medan. Began in August 2017 after obtaining approval from the Research Ethics Commission of Health Division, Faculty of Medicine, University of North Sumatra.

The results of the study are presented in the form of percentage table consisting of data of patient demographic characteristics, observed variable data, and variable data that mutually influenced or allegedly influenced each other

\section{DISCUSSION}

From Table 1, it can be seen that 50 patients with chronic kidney patients undergoing regular HD have fulfilled inclusion; male patients as many as 31 people (62\%) and women as many as 19 people (38\%). From the data obtained, it is known that the number of patients with chronic renal disease regular hemodialysis that is more male than female. One of the factors is due to the smoking lifestyle of men. Smoking behavior can increase the risk of CKD 2.2 times greater than individuals who do not smoke [20].

From Table 2, it can be seen that the age between 20 and 30 years as many as 11 patients (22\%), age between 31 and 40 years as many as 7 patients (14\%), age $41-50$ years is 6 patients (12\%), age between 51 and 60 years as many as 16 patients (32\%), and age above 60 years, that is, 10 patients $(20 \%)$. This indicates that the increasing age, kidney function and blood flow to the kidney is reduced, resulting in a 30\% decrease in glomerular filtration rate compared to younger people [21].

From Table 3, it can be seen that diabetes mellitus as many as 1 patients (2\%), diabetes nephropathy as many as 3 patients $(6 \%)$, chronic glomerulonephritis as many as 5 patients (10\%), hypertension nephropathy as many as 33 patients $(66 \%), \mathrm{HN}+$ CHF as many as 1 patients (2\%), chronic disease obstruksi as many as 6 patients $(12 \%)$, and systemic lupus erythematosus as many as 1 patients $(2 \%)$.

From Table 4, it can be seen that patients with chronic renal disease regular HD 50 people (100\%), i.e. stage 5.

This can happen because in general the symptoms or clinical manifestations of CKD appear suddenly or gradually, and some do not cause clear early symptoms so that the decline in kidney function is often not felt even neglected by the patient and only detected after

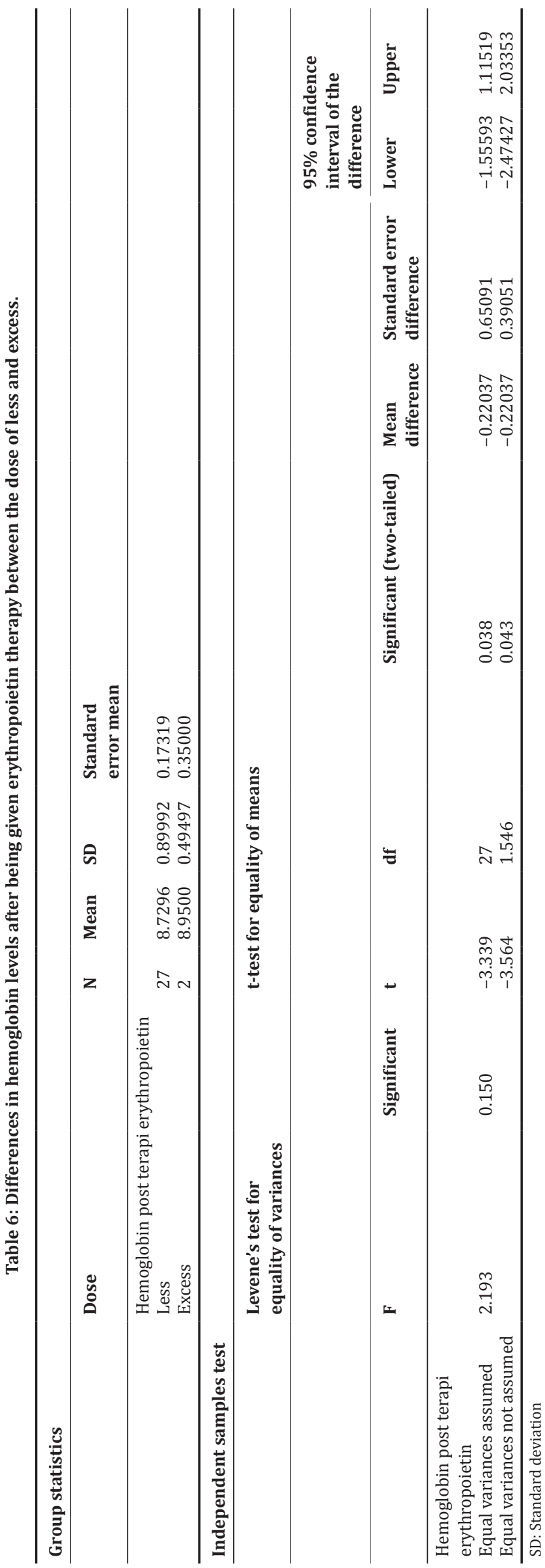


Table 7: Hemoglobin levels before and after erythropoietin therapy using test sample test

\begin{tabular}{|c|c|c|c|c|c|c|c|c|}
\hline \multicolumn{9}{|c|}{ Paired samples test } \\
\hline & \multicolumn{5}{|c|}{ Paired differences } & \multirow[t]{3}{*}{$\mathbf{t}$} & \multirow[t]{3}{*}{ df } & \multirow[t]{3}{*}{ Significant (two-tailed) } \\
\hline & \multirow[t]{2}{*}{ Mean } & \multirow[t]{2}{*}{ Standard deviation } & \multirow[t]{2}{*}{ Standard error mean } & \multicolumn{2}{|c|}{$\begin{array}{l}95 \% \text { confidence } \\
\text { interval of the } \\
\text { difference }\end{array}$} & & & \\
\hline & & & & Lower & Upper & & & \\
\hline \multicolumn{9}{|l|}{ Pair 1} \\
\hline Pre-post EPO & -0.01000 & 0.89994 & 0.12727 & -0.26576 & 0.24576 & -3.079 & 49 & 0.003 \\
\hline
\end{tabular}

the condition of the kidney progressively deteriorate and the clinical manifestations are getting worse in the late stages.

Anemia in CKD is typically normocytic, normochromic, and hypoproliferative. The demonstration of a circulating factor responsible for stimulating erythropoiesis and the EPO deficiency is a predominant cause of anemia in CKD.

From Table 5, it can be seen that the effect of dose-related DRPs less and excess of the target hemoglobin. Based on the results of Chi-square test, obtained $\mathrm{p}=0.015<0.05$, then concluded there is a significant relationship between the dose of less and excessive to the target hemoglobin level.

From Table 6, it can be seen that differences in hemoglobin levels after being given erythropoietin therapy between the dose of less and excess. Based on $t$-test result, $p=0.038<0.05$, there is a difference of hemoglobin level after giving erythropoietin therapy significant between dose less and excess.

From Table 7, it can be seen that hemoglobin levels before and after erythropoietin therapy using a test sample test. Based on paired t-test results, obtained significant value is $0.015<0.05$, then the statistical increase in hemoglobin levels after being given significant erythropoietin therapy [22].

\section{CONCLUSION}

Based on the description, it can be concluded that there is an effect of DRPs related to excessive dosage; less dose to target hemoglobin level with significance value, so DRPs-associated dose affect the target hemoglobin level.

\section{ACKNOWLEDGMENTS}

The author gratefully acknowledges all the parties involved in this research, especially to the Faculty of Pharmacy, University of North Sumatra and RSUP H. Adam Malik Medan.

\section{REFERENCES}

1. Suwitra K. Chronic Kidney Disease. In the Internal Medicine Book. $5^{\text {th }}$ ed. Jakarta: Internal Medicine, Department, Faculty of Medicine; 2009. p. 1035-7.

2. WHO. Hemoglobin Concentrations in the Diagnosis of Anemia and Assessment of Severity. Vitamin and Mineral Nutrition Information System. Geneva: World Health Organization, (WHO/MNH/NHD/ MNN/11.1); 2011.

3. Rsup H, Malik A. Hemodialysis Handbook. Indonesian: Field; 2015. p. 12.

4. Tapan E. Kidney Disease and Hypertension. Medan: PT. Elex Media
Komputindo; 2004.

5. Lee GR. The Normocytic Normochromic Anemias. In: Lee GR, Bithel TC, Foeater J, Athens J, Lukens JN, editors. Wintrobe Clinical Hematology. $9^{\text {th }}$ ed., Vol. 1. London: Lea \& Febringer; 1993.

6. The Indonesian Nephrology Association. Assessment of the Status of Iron and Iron Therapy. Consensus Management Anemia In Chronic Kidney Disease. $2^{\text {nd }}$ ed. Indonesian: The Indonesian Nephrology Association; 2011. p. 11-6.

7. Elsayed AS, Azab AE. Correlation between chronic kidney diseases and hematological data in sabratha hospital in libya. Asian J Pharm Clin Res 2017;10:291-6.

8. Suhardjono A. Cardiovascular disorders in chronic kidney disease. Jakarta: Journal of Internal Medicine; 2009. p. 9-35.

9. National Kidney Foundation (NKF), Kidney Disease Outcome Quality Initiative (K/DOQI). Advisory Board. K/DOQI clinical practice guideline for chronic kidney disease: Evaluation, classification, and stratification. Kidney Disease Outcome Quality Initiative. Am J Kidney Dis 2002;17:19-28.

10. Sjamsiah S. Renal Failure Pharmacotheraphy. Surabaya: Universitas Airlangga; 2005. p. 214

11. American. Society of Hospital Pharmacists. ASHP Statement on Pharmaceutical Care. Am J Hosp Pharm 1993;50:1720-3.

12. Grabe DW, Low CL, Bailie GR, Eisele G. Evaluation of drug related problems in an outpatient hemodialysis unit and impact of a clinical pharmacist. Clin Nephrol 1997;47:115-218.

13. Herlinawati AY, Saurisari R, Andrajat R. Influence of pharmacists' intervention on drug-related problems related to change in hemoglobin levels of hemodialysis patients at adjidarmo hospital. Asian J Pharm Clin Res 2017:10:124-6.

14. Fitrah J. Identification of Drug Related Problems in Open Grade IIIA Fraktur IIIA Patients Treated in Antibiotics at Trauma Center. M. Djamil Padang. Thesis. Padang: University of Andalas; 2011.

15. Wulandari F, Arifin H, Darwin D. Analysis of Drug Related Problems in Patients with Dyspepsia in Inpatient and Outpatient Wards of Internal Medicine Dr. M. Djamil Padang; 2011. Available from: http://www.pasca.Unand.ac.id/id/wp-content/uploads/2011/09/ artikel- tesis- fennyl.pdf. [Last diakses on 2016 Sep 30].

16. Urip HS, dan Hasanul A. Prospective study effect of drug related problems (DRPs) reduction of drug effects on pain patients remover ward in post surgery ortopedi haji adam malik general hospitals in Medan. Int J Pharmtech Res 2013;8:189-92.

17. PCNE. Pharmaceutical Care Network Europe. Available from: http:// www.pcne.org/about -us.php. [Last retrieved on 2016 Aug 21].

18. Raosoft. Sample size calculator. Available from: http://www.raosoft. com/sample size. [Last accessed on 2016 Jan 4].

19. Rsup H, Malik A. Hemodialysis Service Handbook. Medan: Field; 2016. p. 12.

20. Susalit E. Early Diagnosis of Chronic Kidney Disease. Jakarta: Journal of Internal Medicine; 2009. p. 9-12.

21. Wilson M. Chronic Kidney Failure. In: Price AS, Wilson ML, editors. Clinical Pathophysiology of Disease Processes. Jakarta: EGC; 1995.

22. Khairunnisa C, Hari Ronaldo T, Dadang Husori. Pharmacy Statistics Practicum Guide. Medan: USU Press; 2013. p. 84. 